\title{
Converting a Political Goal to Reality: The First Steps to Materialize Mongolia's Nuclear-Weapon Free Status ${ }^{\star}$
}

\author{
J.Enkhsaikhan (Mongolia)
}

\section{Introduction}

T $\mathrm{n}$ this article the author documents chronologically the initial steps taken by Mongolia to promote its initiative to turn its territory into a nuclearweapon-free zone by having the General Assembly of the United Nations acknowledge and express support for such a status. This is not an analytical but a chronologically descriptive article that is based on the materials available to the Mongolian side only. It does not cover the discussions that the five nuclear-weapons States (the P5) ${ }^{1}$ had when preparing responses to Mongolia's various substantive or procedural proposals, nor the discussions held in their capitals on either how to respond bilaterally to Mongolia's suggestions or as P3 (US, UK and France) or P5. As with achieving durable peace, establishing a credible nuclear-weaponfree zone status is both a goal and a process. In this case the goal can be achieved through collective efforts and gradually. The process will continue until a viable status is established that would form part of an internationally agreed nuclearweapon-free regime. To achieve this goal close cooperation is needed. The article will describe the Mongolian example of how multilateralism and mutual understanding are essential in addressing the challenges that the international community is facing in this increasingly interdependent world. Competition, cooperation and compromise are the indispensable approaches and tools to address these and other international goals and challenges. When undertaking this chronology of the measures taken to have the General Assembly of the United Nations adopt in 1998 its first resolution on Mongolia's nuclear-weapon-free status, the author, as still public servant, deliberately refrained from making in-depth analysis or value

\footnotetext{
* This article is dedicated to the 20th anniversary of the Mongolian initiative. Time-wise it covers the first seven years that have laid the foundations for promoting the initiative towards its institutionalization. 1 P5 means the nuclear-weapon states recognized by the NPT, i.e. the People's Republic of China, France, the Russian Federation, the United Kingdom and the United States of America.
} 
judgments of the positions taken by Mongolia or the P5 separately or as a group with respect to the substance of the issues involved or procedures followed.

The author was privileged to have served as the Mongolian counterpart in many meetings held either bilaterally with the P5 states or with the P5 as a group. At the initial stage, Mongolia's main counterpart was the US Ambassador to Mongolia. When the issue was brought to the United Nations General Assembly in 1997, the main counterpart was Ambassador John King, US delegate to the Conference on Disarmament, who represented not only the US, but at times the P3 and the P5. He spent enormous amount of time with the author to find possible ways and means to address Mongolia's legitimate interests bearing in mind, of course, the interests of the US and the other P4. Numerous officials on both sides have participated in the discussions on how to promote the initiative and in the preparations of different drafts that in the end led to the adoption by the General Assembly of resolution 53/77 D on 4 December 1998. In order not to confuse the reader with many names, the author avoided putting various names and titles without detriment to the content of their statements and comments.

As to the issue itself, it took Mongolia six years to have the General Assembly welcome and support the initiative in the form of the first resolution entitled "Mongolia's international security and nuclear-weapon-free status". Although the issue appears on the General Assembly's agenda every second year, not much progress has been made since 1998 to institutionalize the status.

\footnotetext{
Brief timeline of 1992-1998 events
1992 - President P. Ochirbat declares Mongolia's territory a NWFZ and commits to work to have that status internationally guaranteed.

1993 - Treaty on Friendly relations with Russia is signed whereby the latter commits to respect Mongolia's policy of not admitting the deployment on and transit through its territory of foreign troops, nuclear and other weapons of mass destruction

-US commends Mongolia's policy and announces that "if Mongolia ever

faces a threat and decides to refer the matter to the United Nations Security Council, the United States, along with other members of the Council, would consider appropriate steps to be taken.

1994-95 - Mongolia undertakes consultations with the five nuclear-weapon states (P5) for a joint statement in support of Mongolia's NWFZ

1996 - Mongolia explores the possibility of joining a future Central Asian NWFZ.

1997 - Mongolia submits to the United Nations Disarmament Commission a working paper on the concept of establishing single-State NWFZs

-the United States, the United Kingdom and France (P3) make a joint demarche in connection with Mongolia's plan to submit to the United Nations General Assembly (UNGA) a resolution in support of Mongolia's initiative. The P3 consider it as "premature, unhelpful, possibly counter-productive" and urge it not to table any resolution in 1997

-Agreement with the United States to postpone the draft resolution for a year and to work for a common understanding on how to proceed

1998 - Mongolia consults with the P5 through the United States on a possible UN General

Assembly resolution regarding recognition of its NWFZ

-P3 make a 3-point proposal regarding Mongolia’s conventional security.

Mongolia declines the ideas as not addressing its nuclear security concerns.

-UNGA adopts resolution 53/77D entitled "Mongolia's international security and nuclear-weapon-free status" that expresses support for Mongolia's policy, decides to include the item on its agenda for 2000 and requests the Secretary General to report on its implementation.
} 
As of this writing the status has not yet been defined internationally. Eleven years after the adoption of the first resolution, Russia and China have agreed, though reluctantly, to hold consultative meetings with Mongolia and to have a preliminary discussion of a draft trilateral treaty that the latter had presented to them in 2007. The P3 has also been invited to consider joining the discussion at some appropriate stage. Although the goal has not been achieved, the process is continuing to find a mutually acceptable solution to this issue that can affect the balance of power and interests in North-East Asia.

\section{Putting the issue in an historical context}

The twentieth century history of Mongolia is a history of its efforts to preserve and strengthen the independence regained from the Manchu rule in 1911, to have that status recognized by its two immediate neighbors - Czarist Russia and the emerging Republican China. The 1915 trilateral Kiakhta agreement marked the first step in balancing the interests of Mongolia's neighbors and at the same time providing conditional autonomy to Mongolia. In the early 1920's, with the consolidation of Soviet rule in Russia, Mongolia became a Soviet satellite State. This had its advantages and disadvantages. The advantage was that having aligned itself with the rising Soviet State, it felt more secure from possible Chinese encroachments on its sovereignty and territorial integrity.

On the other hand, it had to toe the Soviet line both in internal politics and foreign policy, at times to the detriment of its own national interests. Officially, the former Soviet Union did not accept the concept of "national interest" of Mongolia. Its policy was based on the doctrine of class struggle and solidarity with the "working class" of the world, headed by the Soviet Union. Proceeding from that doctrine, Mongolia approached its security policy through the so-called class struggle principles: State security rather than national security was emphasized, which boiled down to the simplistic rule of defending "socialism" inside and outside of the country. The search for enemies inside Mongolia led to such "sacrifices" as annihilating a considerable number of its citizens as class enemies. The search for enemies outside of the country lead to cutting off its nascent trade and other ties with the US, Germany and other countries, and thus to isolating itself from the rest of the world except, of course, from the Soviet Union.

In the early post-World War II years, following the creation of the People's Republic of China, Mongolia found itself surrounded by two communist States, which raised the hope for harmony and all-round cooperation among the three countries. However, these hopes were dashed with the subsequent Sino-Soviet split by the end of 1950s. The seemingly ideological split by the mid-1960s grew into an overt interstate Sino-Soviet hostility. Unable to be 'neutral' in the conflict, Mongolia sided with the Soviet Union. Thus, from the 1960s to the end of 
1980s Mongolia was victim of two prolonged and costly "cold wars": East-West and Sino-Soviet.

In the East-West conflict, Mongolia firmly sided with the Soviets, including on the questions of international security, arms control and disarmament. In January 1966, it signed a treaty of friendship and cooperation with the Soviet Union, which pledged, in Article 5 of the treaty, to assist Mongolia in case of an external attack. When the Sino-Soviet dispute acquired an interstate character by the mid1960s, both the Soviet Union and China had heavily fortified their common border. In 1967, the Soviet Union introduced its troops into Mongolia. Soon Mongolia's two neighbors with numerically the strongest armies in the world (around 4.7 million in China and 2.9 million in the Soviet Union) were confronting each other, with the Soviet Union having up to 52 divisions stationed in its eastern border regions, including 4 divisions in Mongolia. In its turn, China deployed almost 1 million men in the adjacent military regions of Sinkiang, Lanchou, Beijing and Shenyang. While the dispute grew tense, the Soviets perfected their nuclear arsenal, and China, having successfully tested its nuclear weapon in 1964, began developing various types of nuclear weapons, from tactical to strategic. It is estimated that in 1964 while the Soviet Union had 5.221 nuclear weapons China had deployed its first such weapon.

At the height of Sino-Soviet conflict in 1969, when armed clashes occurred along some parts of their border, Moscow had around 10.538 and China already around 50 nuclear weapons ${ }^{2}$. Moscow had around 60.000-75.000 troops, including two tank and two motorized rifle divisions, plus unspecified air force units stationed in Mongolia. Some of the troops are thought to have been equipped with nuclear-capable intermediate range-ballistic missiles.

Having sided firmly with the Soviets in the Sino-Soviet dispute and having allowed the stationing of Soviet troops on its territory, Mongolia was no longer only a strategic buffer for the Soviets against China. It also served as a potential springboard from which the Soviets could launch a blitzkrieg-type military offensive into northern China, if not into Beijing.

In the late 1960 s and early 1970 s, the Soviets seemed to have been tempted to undertake a preemptive nuclear strike on Chinese nuclear installations. It therefore was no coincidence that Soviet military experts and strategists were writing at that time that "along with conventional war and instantaneous nuclear war of incredible magnitude and devastation, war involving the restricted use of nuclear weapons in one or more theaters of military operations should not be

2 Robert S. Norris and Hans M. Kristensen. Global nuclear weapons inventories, 1945-2010. Bulletin of Atomic Scientists. July/August 2010. p. 81. 
excluded." 3 It was also assumed that since China was the Soviet Union's potential adversary, in case of a war between the Soviet Union and its Warsaw Pact allies on the one side, and the United States and also NATO on the other, a perceived second front, i.e. between the Soviet Union and China, might involve the use of nuclear weapons. ${ }^{4}$ Histories and memoirs of the political events in the late $1960 \mathrm{~s}$ indicate that indeed at some time the Soviets entertained the idea of the possibility of preemptively striking against the fledgling Chinese nuclear arsenal and facilities. This is confirmed by the post-cold war writings of US, Russia and even Chinese statesmen and scholars such as former US Secretary of State Dr. Henry Kissinger, former Soviet Ambassador to US Anatoly Dobrynin, Chinese scholar Liu Chenshan ${ }^{5}$ and others. Thus, Liu Chenshan published a study in May of 2010 which recounts five instances in the early history of the PRC when it was threatened by nuclear weapons. In his article Mr. Chenshan underlines that the most serious threat was in 1969 at the height of the Sino-Soviet border dispute and clashes that claimed the lives of around 1000 military personnel. According to Dr. Kissinger, the Soviets had approached the U.S. to 'sound out' the US reaction in case the Soviet Union were to make a 'surgical' strike against the Chinese nuclear arsenal. Soviet Ambassador to US, A. Dobrynin, wrote that he had told the Soviet leader L. Brezhnev at that time that the US response to the Soviet "sounding" was negative and that the US had warned that if China suffered a nuclear attack it would be considered as the start of the third world war. It seems that the US geopolitical calculation was that since it perceived a greater threat from the Soviet Union than from the PRC, it thought that a stronger China would counterbalance Soviet power. Had the US indicated that it would remain 'neutral' to a Soviet surgical strike, the 1962 Cuban missile crisis would have been a footnote compared to possible Sino-Soviet clashes.

Since Mongolia was considered an important bastion of socialism in Asia, its territory was expected to play a strategic role in a potential Sino-Soviet confrontation or war. However, the nature of the Soviet-Mongolian "alliance" and of the Brezhnev doctrine in general meant that the ultimate decision to use force, including perhaps nuclear weapons, would have been taken by the Soviets themselves, without real consultation with the Mongolian side. The latter probably would have been informed of the decision ex post facto. In other words, the Mongolians would not have had a voice in the decision to use force from Mongolian territory. Therefore, its role as a 'strategic bridgehead' in the potential conflict meant that in case of a conflict, Mongolia would have surely been turned into a battlefield, perhaps even with the use of nuclear weapons.

\footnotetext{
3 V. Sokolovsky and M. Cherednichenko "Voyennaya strategiya i yeye problemy" (Military strategy and its problems). Voyennaya mysl', No. 10, 1968. p. 36

4 see Voyenniy entsiklopedicheskii slovar' ( Military encyclopedic dictionary), Moscow, Sovyetskaya entsiklopediya. 1983. p.842. This concept of "limited" nuclear war was later abandoned by the Soviet military theory once the practical impossibility of containing nuclear war within predetermined bounds was recognized. 5 Chenshan
} 


\section{New realities, policies and opportunities}

The Soviet agreement in the late 1980s to withdraw its forces from Afghanistan and Mongolia, as well as to ensure withdrawal of Soviet-backed Vietnamese forces from Cambodia opened the way for normalization of Sino-Soviet relations. The subsequent end of the East-West and Sino-Soviet cold wars, the disintegration of the so-called socialist world and of the Soviet Union itself have fundamentally changed Mongolia's geopolitical environment. These changes have opened up the opportunity to abandon its one-sided pro-Soviet policies, and, for the first time in three hundred years, to define and pursue its own national interests and priorities, bearing also in mind the vital interests of its neighbors.

In this new geostrategic environment, Mongolia abandoned its reliance on one state for its security and promote ideologically oriented domestic and foreign policies, and adopted a "multi-pillared" foreign policy, hence diversifying its foreign relations beyond its immediate neighbors. This major pragmatic turn found its reflection in the "Concept of Foreign Policy of Mongolia", adopted by the State Great Khural (the Parliament) of Mongolia in June 1994. The concept thus declared that Mongolia's foreign policy would henceforth be based on political realism, non-alignment and pursuit of its own national interests as reflected in the 1992 Constitution, and that its priority would be to safeguard its security and vital national interests primarily by political and diplomatic means. While championing its national interests, it pledged to respect the legitimate interests of its neighbours and partners. Mongolias national security concept defined disputes and conflicts between the neighbouring states as potential threats to its security and declared that ensuring the nuclear-weapon-free status of Mongolia at the international level was an important element of strengthening the country's security by political means.$^{6}$

\section{Mongolia declares its territory a NWFZ (1992)}

Bearing in mind the importance of ensuring national security by political and legal means, President Ochirbat, when making a statement in the general debate of the General Assembly of the United Nations in September 1992, announced that Mongolia was declaring its territory a nuclear-weapon-free zone and would be working to have that status "internationally guaranteed". At that time the declaration (i.e. the initiative) did not have a sensational effect in Mongolia nor internationally. It was seen, naturally, as one of the declarations of Heads of State addressing the General Assembly.

A few months later ensuring the nuclear-weapon-free status of Mongolia found recognition and reflection in Mongolia's treaty on friendly relations and cooperation signed in January 1993 with the Russian Federation, in which the 6 See The Concept of National Security of Mongolia. Ulaanbaatar, 1999. Paras. 21.10 and 23.5 of the concept. 
Russian Federation pledged to respect Mongolia's policy of not permitting the deployment on and transit through its territory of foreign troops, nuclear and other weapons of mass destruction ${ }^{7}$. That was the first concrete expression of support of Mongolia's initiative by its northern neighbour.

However, a concrete work plan to promote the idea of Mongolia's NWFZ and to work for its realization came later, when the international community started to prepare for the 1995 review conference on the Treaty on the Non-Proliferation of Nuclear Weapons (the NPT). The United States and the other four nuclearweapons states were interested in having the treaty extended for an indefinite period, and hence needed the support of other states, especially of non-nuclear weapons States Party to the NPT. Mongolia decided to use this interest of the P5 to put its initiative on the 'negotiating' agenda with them, since it believed that recognition and institutionalization of Mongolia's nuclear-weapon-free status (i.e. making it an official process but not necessarily setting up of a special body or organization) would not only be an important regional confidence-building measure, but also a conflict prevention and even an early-warning measure, since no one can forecast with certainty that history would not repeat itself under situations which would be somewhat different yet in essence similar to those in 1969 mentioned earlier.

\section{Quest for the P5 support (1993-1995)}

In early 1993 the United States approached Mongolia, as it did many other non-nuclear weapon states parties to the NPT, with a request to support the indefinite extension of the treaty. The Mongolian side, mindful of the Mongolian President's initiative, in return requested the United States to express its support for the initiative.

Following the first meeting on this issue on 7 May 1993, the Executive Secretary of Mongolia's National Security Council met with the US Ambassador to Mongolia J. Lake and proposed a draft of a possible US Statement in connection with the Mongolian President's initiative. The draft would say that at the time when the danger of nuclear weapons proliferation was persisting, the United States fully supported Mongolia's non-nuclear policy and was prepared to assist in its implementation. It would also say that the US was also prepared to consult and work with the Mongolian side on the issue of promoting Mongolia's security interests.

The US response came on 22 June. Having considered Mongolia's request and the proposed draft, the US explained its basic position regarding NWFZs and Mongolia's initiative. Thus, the US stated that it did not see a specific role for itself

7 See Article 4 of the Treaty on Friendly Relations and Cooperation between Mongolia and the Russian Federation of 20 January, 1993. 
in implementing Mongolia's proposed initiative, that by adhering closely to the letter and spirit of the NPT, Mongolia already benefited from the US commitment to seek Security Council assistance for non-nuclear-weapons States Party to the NPT in the event of a nuclear attack on them as well as from its assurances that it would not use nuclear weapons against a non-nuclear state not allied with a nuclear weapon state. He suggested that Mongolia could cite these existing US security guarantees or, if needed, the US could consider issuing a Statement using somewhat similar language. He said that the US did not wish to specifically endorse Mongolia's nuclear-weapon-free zone (NWFZ) for technical and legal reasons and that Mongolia's announcement did not warrant security guarantees beyond the ones that US had already given to all non-nuclear states parties to the NPT.

During the meeting on 22 June 1993 the US Ambassador pointed out that Mongolia did not in fact constitute a regional NWFZ and that even with respect to regional zones the United States was selective when formally associating itself with such zones. Thus, for example, the United States had signed and ratified the protocols to the Tlatelolco treaty, ${ }^{8}$ but had not signed those to the Rarotonga treaty. ${ }^{9}$ Therefore any consideration of specific endorsement of a NWFZ would require a closer look at all the provisions regarding its establishment, including its relationship to the exercise of the rights recognized under international law such as the right of transit. That was why any consideration of formal endorsement by the US of Mongolia's NWFZ policy would require, at a minimum, a clear and detailed understanding of how the Government of Mongolia intended to implement it. However, the Ambassador noted, the US would have no objection if Mongolia would cite existing US security assurances under the NPT. Ambassador Lake then presented "points to draw on for possible publication", for a careful consideration by the Mongolian side.

The "points to draw on" would commend the decision to declare Mongolia a nuclear-weapon-free zone and welcome its decision to support the indefinite extension of the NPT in 1995. It would also state that Mongolia benefited from the US commitment to seek Security Council assistance for non-nuclear-weapons States Party to the NPT in the event of a nuclear attack on them as well as from US assurances that it would not use nuclear weapons against a non-nuclear state not allied with a nuclear-weapon state.

The Mongolian side, having listened to the US position on NWFZs in general, and on Mongolia's initiative, and having had a cursory look at the "points to draw on" noted that it was difficult to comment off-hand on "the points". The U.S. Ambassador suggested to take some time to study carefully the draft and to get back

8 Treaty for the Prohibition of Nuclear Weapons in Latin America of 1967. Later, in 1990 the scope of the treaty was expanded to cover the Caribbean countries as well.

9 South Pacific Nuclear Free Zone Treaty of 1985. 
to him with, if any, some possible amendments and proposals that in

Mongolia's view could be reflected in "the points to draw on" bearing in mind the general policy of the US on the issues concerning NWFZs outlined earlier.

Two days later the Mongolian side presented a somewhat re-drafted version of the "points to draw on" to the US Ambassador and explained the proposed changes. Instead of providing positive and negative security assurances, the revised draft would say that Mongolia would ...benefit from US commitments made unilaterally and together with other members of UNSC in 1968 with respect to non-nuclear weapon States Party to the NPT. It would also say that should a threat arise from a nuclear-weapon state to use force against Mongolia, the US would be prepared to consult with Mongolia, with other members of UNSC, and to offer it political assistance or its mediation.

Soon thereafter, the United States proposed its own revised draft, which omitted reference to Mongolia, and referred to a victim of nuclear weapon use. The gist of the draft stated the following: "Should a threat arise from a nuclear weapon State to use force against a non-nuclear weapon State, the United States would seek immediate Security Council action to provide assistance, in accordance with the Charter, to any non-nuclear weapon State Party to the NPT that is a victim of an act of aggression or an object of a threat of aggression in which nuclear weapons are used". Since the draft failed to mention Mongolia by name, the Mongolian side was reluctant to discuss such a draft.

Bearing in mind Mongolia's reluctance, the United States proposed on 1 October another draft which followed US standard formulations on positive and negative security assurances and pointed out that these assurances were addressed to Mongolia as well, and that US noted that other nuclear-weapons states had provided similar assurances. As an inducement, it also proposed the following language: "If Mongolia ever faces such a threat and decides to refer the matter to the United Nations Security Council, the United States, along with other members of the Council, would consider appropriate steps to be taken". The Mongolian side in principle agreed with such a Statement, however it proposed that the text should not refer only to "such a threat", i.e. to nuclear threat, but to any threat, since it is the prerogative of UNSC to consider any threat to international peace and security and limiting the Statement only to a "nuclear threat" would not be in keeping with the UN Charter. After some discussion and consultations with Washington, the US side agreed to such language. On 6 October, the US Department of State made the Statement (see Annex-1).

The US Statement opened the way for other P5 countries to express their support for Mongolia's initiative. Thus on 22 October China welcomed and expressed support of Mongolia as a nuclear-weapon-free State, and declared that it would not only respect its policy of turning its territory into a NWFZ but also under- 
lined that China's pledge not to use or threaten to use nuclear weapons against NWFZs or states also applied to Mongolia.

On 1 November, the United Kingdom made a Statement in which it said that the positive and negative security assurances that it was providing to all non-nuclear States Party to the NPT applied to Mongolia. For a state which was no longer in an alliance with any nuclear-weapon state and was trying to institutionalize in practice its single-state NWFZ status, it was unimaginable for the United Kingdom to threaten, let alone attack, Mongolia through either Russian or Chinese territory or air space. The UK's statement of support was a good indicator that the P5 were supportive in general of Mongolia's initiative and policy.

In January 1994, France also made a Statement whereby it welcomed the decision of the Government of Mongolia to declare itself a NWFZ and announced that it was providing Mongolia with negative security assurances. With the French statement, all P5 had expressed their support for the initiative. Of the P5, the Russian Federation was the only one that had committed in treaty form to respect Mongolia's policy. The other four nuclear-weapons states simply declared that the positive and negative security assurances that they had pledged to non-nuclearweapons states applied to Mongolia. However, amongst the five, only the United Sates had taken an extra step by declaring that if Mongolia ever faced a threat and decided to refer the matter to the United Nations Security Council, the United States, along with other members of the Council, would consider appropriate steps to be taken. Although by the end of January 1994 the P5 had officially reacted positively to the initiative, Mongolia's hope to have the status "internationally guaranteed" was yet to be fulfilled.

\section{Quest for a joint P5 statement of support (1994-95)}

In order to take the first steps to have the status "internationally guaranteed", in the Spring of 1994 Mongolia drafted a P5 Joint Statement (JS) regarding Mongolia's declaration of its territory as a NWFZ that would declare that the P5 would respect its nuclear-weapon-free status, and that in case the status or Mongolia's national security were to be threatened from outside and Mongolia decided to refer the matter to the United Nations Security Council, the P5 would take all necessary measures for the Council to eliminate such a threat (see Annex-2). The first country consulted regarding the draft P5 JS was Russia, when the Executive Secretary of the National Security Council of Mongolia paid an official visit to Russia in June 1994. The Russians offered minor technical changes to the proposed draft and in principle agreed to the text as a whole. Both Deputy Foreign Minister S. Lavrov and Secretary of Russian National Security Council O. Lobov agreed to support Mongolia's efforts. 
Having obtained Russia's support, the next step was to get a reaction to the draft P5 JS from the United States. Its Ambassador to Mongolia, after having consulted with Washington, declared that the United States was prepared to look at the issue positively if it were to be officially presented to the United States. At the same time he cautioned that the JS should not go beyond the US Statement of October 1993 and that the US would not take any initiative to have the issue discussed among the P5, meaning that it would be up to Mongolia itself to approach each one of the P5 with the proposal. As a follow-up on US Ambassador's suggestion, Mongolia officially asked the US to consider the content of the draft JS. In response to the official request, the US reiterated its position outlined earlier and said that it would first and foremost look into the language to make sure that it was in accord with its NWFZ policy and did not go beyond standard US security guarantees provided to non-nuclear weapons states. Having examined the draft, in August 1994 the US proposed to replace the language concerning the "threat to Mongolian status or national security" by a language reflected in its 1993 US Statement and to add an emphasis that the appropriate steps to be taken would be "as provided in the UN Charter".

Having obtained the agreement, if not outright support, of Russia and the United States, Mongolia presented the draft to the P4 Ambassadors in Ulaanbaatar at the end of August. ${ }^{10}$ The first reaction came from Russia, which stated that it had no objection to the text even with the US amendment and advised Mongolia to obtain responses from the UK, France and China, and that if all agreed, the text could be finalized in New York at a meeting of the P5 and Mongolia, and could be circulated as a document of the Security Council. Russia emphasized that since the issue concerned exclusively the P5 and Mongolia, there was no need to have consultations with the non-permanent members of the Council.

The Chinese reaction to the draft JS was also swift. It pointed out that it supported Mongolia's initiative to have a P5 JS and would carefully study the text. At the same time it advised Mongolia to work closely with the other P4.

The United Kingdom enquired as to why the text in paragraph 5 did not have the adjective "nuclear" when qualifying the threat and whether the JS would set a precedent. Mongolia's response to the first question was that since the paragraph dealt with the prerogatives of the Security Council, it would not have been correct to limit its prerogative to only "nuclear" threats. Besides, Mongolia would more likely feel threatened by more traditional forms of threats and pressures rather than by nuclear weapons. As to the second question, Mongolia explained that while it already had separate assurances from its neighbors, multilateral assurances were more credible and would involve all the P5. It was pointed out that it would not be a carte blanche guarantee, and that it would be a political declara-

10 France at that time did not have an Embassy in Mongolia and the draft was transmitted through Mongolian Embassy in Paris. 
tion, not a legally binding commitment. It was explained that this would not mean that the Security Council or the P5 would do what Mongolia wanted them to do, nor that any of the P5 would be constrained in vetoing any decision. The UK representative said that in principle the United Kingdom had no objection if the other P4 would support it. It recommended that the issue be pursued in New York through the United Nations.

Encouraged by Russias somewhat positive reaction, Mongolia asked it to organize P5 consultations with Mongolia in New York to promote the idea of the JS. However, no concrete response was received to this request. Among the somewhat positive responses from the other P4, the French response was very important. However, as expected, it was more elusive than that of the others. Its Ambassador to Mongolia indicated that the main parties within the P5 were the United States and Russia, and that their support was crucial. When pressed about the French position, he said that it was difficult for France to agree with the JS, since it could mean that many of the Francophone countries would want security assurances from France and it would be difficult for his government to explain why it was prepared to provide security assurances to Mongolia but not to Francophone countries.

During the meeting he advised Mongolia to pursue the issue not with individual nuclear-weapons states but rather with the P5 as a group, perhaps at the United Nations. In order to preempt any pretext for not supporting the JS (since the French approach to NWFZs was more restricted than those of the others due to their testing of nuclear weapons in the South Pacific) Mongolia specifically pointed out that what it was after was not a legally binding commitment that would firmly commit the P5 or a security assurance that had been provided by the P4 to Ukraine, Belarus or Kazakhstan, but rather a political declaration. It was also pointed out that the provision that the "Security Council...would consider appropriate steps to be taken" was not meant to give Mongolia a carte blanche but rather referred to the steps that could be taken within the UN Charter and accepted Security Council procedures.

The French did not respond until a few months later. In its response it explained that France was reviewing its policy regarding nuclear security assurances prior to the NPT Review Conference in 1995, which would most probably last until the end of the Presidential elections to be held in May 1995, and that it would also be difficult for France to adopt a positive attitude towards the JS when it was conducting nuclear-weapon tests in the South Pacific. That was the reason why, according to the French Ambassador, France had to make Statements separate from United States, United Kingdom and the Russian Federation, in the cases of Ukraine, Belarus and Kazakhstan. Just prior to the NPT Review Conference, France indeed joined the P4 in making a Joint Statement with respect to security 
assurances for non-nuclear-weapons states.

In November, when discussing how the draft JS text could be improved, the US signaled that it could add a phrase in the JS to the effect that the P5 "commended Mongolia for its decision to declare a NWFZ" if the JS could be agreed and adopted by the P5. That was a nice gesture on the part of the United States.

In December 1994, Russia signaled that although in principle it was not objecting to the draft JS text, it would be ready to make such a statement with respect to the nuclear-weapon-free status of Mongolia if other nuclear-weapons states would do the same.

The NPT Review Conference was held in May 1995. A month earlier, in order to get broader support from the non-nuclear-weapons States Parties to the NPT, the US, Russia, UK and France individually made declarations providing both positive and negative security assurances to the non-nuclear-weapon States Parties, which in April 1995 was reflected in UN Security Council resolution 984. For its part, China reiterated that it would not use or threaten to use nuclear weapons against non-nuclear-weapon states or nuclear-weapon-free zones at any time or under any circumstances. After the NPT conference, the pressure on the P5 had visibly diminished, and with it the chances of having the P5 JS also diminished.

After having waited for some time for the French review of its policy with regard to nuclear security assurances and its Presidential elections, in September 1995 the Executive Secretary of the Mongolian National Security Council made a working visit to Paris to meet with the officials that dealt with nuclear policy issues, including the advisor to the Prime Minister and officials of the French Ministry of Foreign Affairs. Since there was a sense that there was inadequate understanding of Mongolia's position, the Executive Secretary explained in detail the rationale behind the JS. However, he was not able to convince the French, who announced that they could not support the JS. Thus, the P5 JS issue was officially blocked and a new approach to promoting the initiative was needed.

\section{A multilateral approach to promoting the initiative (1995)}

Given the general reluctance of the P5 to support a JS on Mongolia's NWFZ as expressed by the French response, Mongolia decided to broaden its approach to promoting its initiative and to enlist the support of other states. It turned to the Non-Aligned Movement (NAM), which in October 1995 held its XI Summit in Cartagena, Colombia. Mongolia's initiative was positively received, and the Final Document of the NAM Summit welcomed the unilateral declaration by Mongolia of its territory as a nuclear-weapon-free zone as "a commendable contribution to regional stability and confidence building". This was a Statement of Heads of State and Government of over 110 countries and hence gave strong political support and inspiration to Mongolia to promote further its initiative. The first step in 
multilateralizing the promotion of the initiative had been made.

\section{Decision to go to UN General Assembly to legitimize the status (1995)}

By the end of 1995, Mongolia decided that the most appropriate multilateral forum for promoting and legitimizing its NWFZ status would be the United Nations General Assembly, the overwhelming majority of whose membership was non-nuclear-weapon states that were demanding negative security assurances from the P5, and some of which were working to establish NWFZs in their part of the world. Although Mongolia's main negotiating partners would still be the P5, including its two immediate neighbors, the broad approach, it was thought, would provide Mongolia with greater political leverage and a political tool to promote further its initiative. According to the universally agreed definition of NWFZs, as approved by UNGA resolution 3472 (XXX) of 1974, acceptance by the latter was one of the important criteria for an arrangement to be considere as a NWFZ. ${ }^{11}$ While Mongolia's NWFZ did not fit into the traditional definition of a NWFZ, since it was acting on its own and not in concert with other states of the region, this did not discourage it from trying to break new ground both in the theory and practice of establishing NWFZs. ${ }^{12}$

When bringing this issue to the General Assembly, it was decided that Mongolia should not limit itself to a mere Statement or a declaration, as was the case with the P5 JS, but should instead aim for a novel yet full-fledged NWFZ status with legally binding security assurances from the P5 and institutionalized internationally. Mongolia was not in a desperate rush, since the relations among the P5 and especially between Mongolia and its immediate neighbors were good and thus there was no imminent threat to its security. Mongolia could afford to promote the initiative slowly, step by step. Promoting a NWFZ was both a goal and a process. It was decided to put formally the issue on the Assembly's agenda and work for the latter's formal approval of the status. Also at that time Mongolia saw a good opportunity to press its case in the United Nations Disarmament Commission (UNDC), a subsidiary body of the General Assembly that, in 1997 was planning draft guidelines for establishing new NWFZs.

The ministerial meeting of NAM, held in New Delhi in April 1997, ac-

11 The General Assembly resolution partly read as follows: A "nuclear-weapon-free zone" shall, as a general rule, be deemed to be any zone, recognized as such by the General Assembly of the United Nations, which any group of states, in the free exercise of their sovereignty, has established by virtue of a treaty or convention whereby"

(a) The statute of total absence of nuclear weapons to which the zone shall be subject, including the procedure for the delimitation of the zone, is defined;

(b) An international system of verification and control is established to guarantee compliance with the obligations deriving from that statute."

12 The same UNGA definition of NWFZs regarding the scope of the definition specifically underlined that it in no way impaired the resolutions which the General Assembly has adopted or may adopt with regard to specific cases of nuclear-weapon-free zones nor the rights emanating from the Member States from such resolutions. 
knowledged and welcomed Mongolia's efforts to institutionalize its status as a NWFZ. Multilateral support for the initiative was increasing, which assured broad, if not unanimous, support at the United Nations General Assembly.

\section{a) promoting the concept of a single-State NWFZ in the UNDC (1997-99)}

An appropriate international forum for focusing on NWFZ issues and especially clarifying the position of Russia and China regarding Mongolia's initiative as well as its possible participation in a future Central Asian NWFZ was the First Committee of the General Assembly that considered issues of disarmament and international security. Thus, in 1996 Mongolia, together with Kyrgyzstan, drafted and circulated a resolution ${ }^{13}$ whereby the General Assembly would welcome the intention of the States of Central Asia to establish a NWFZ, commend Central Asian States that had declared their territories a NWFZ (in this case implicitly meaning Mongolia) and called upon the P5 and other States to support the idea of a single-state NWFZ zone, extend the necessary cooperation and refrain from any action that would go contrary to the spirit of that objective.

The reaction of the P5 to the draft resolution was lukewarm, while the other Central Asian States "needed instructions from their capitals" to decide on the possible co-sponsorship of the resolution. The lukewarm reaction of the P5 indicated that Mongolia's participation in a Central Asian NWFZ would not be wholeheartedly supported. To clarify further the position of its immediate neighbors that mattered most, Mongolia approached Russia and China on this issue. Both of them immediately let Mongolia know that they would have difficulties in seeing Mongolia included in any possible future Central Asian NWFZ, since it did not border on any Central Asian State, and that about $50 \mathrm{~km}$ of Russian territory would have to be included in the NWFZ if Mongolia were to be a part of that zone, to which Russia would not agree. China also indicated its reluctance in seeing Mongolia as part of a NWFZ that did not have the support of Russia. With Russian and Chinese positions clarified, Mongolia was ready to promote the novel idea of a single-State NWFZ based on the UN comprehensive study on NWFZs of 1975 and endorsed by the General Assembly in its resolution in $1976 .^{14}$

The first step in putting Mongolia's issue on the agenda of UNGA was to propose that the issue of establishing a single-State NWFZ be discussed in the UNDC when it started drafting guidelines for establishing new NWFZ sin the spring of 1997. With that in mind, on the second day of UNDC's substantive session Mon-

13 See UNGA document A/C.1/51/L.29 of 29 October 1996

14 Resolution “Comprehensive Study on the Question of Nuclear-Weapon-Free Zones in All Its Aspects” was adopted on 10 December 1976 
golia submitted a working paper ${ }^{15}$ formulating the concept of establishing singlestate NWFZs in cases where traditional (group) zones cannot be established. The working paper laid out the principles of establishing such zones, elements of a model agreement establishing such zones and the practical steps for considering single-state NWFZ guidelines in the UNDC that would coincide with the consideration of the guidelines for establishing new NWFZs ${ }^{16}$. To give some 'incentive' for discussion of this concept, the working paper also reproduced the commitments made by the nuclear-weapons states in connection with

Mongolia's declaration of its territory as a NWFZ, as evidence of acceptance in principle of the notion of single-state zones.

As expected, many developing countries, in line with the NAM's earlier statements on the issue, welcomed this new angle of approaching the establishment of NWFZs, agreeing with Mongolia that life was rich in diversity and that the cases of individual states needed to be also addressed, which is foreseen and mentioned in the 1975 comprehensive study of the United Nations of the NWFZs in all their aspects. However, the P5, which were important actors and factors in making NWFZs effective, were silent.

When some developing countries began making reference to Mongolia's proposal during the general debate, the representatives of the P5 approached the Mongolian delegation to say that since Mongolia was an exceptional case, it would not be proper to have the concept of single-state zones considered together with establishing traditional zones and that, frankly speaking, the P5 needed time to carefully study the single-state concept and its implications for existing security arrangements. Mongolia's reply was that although it would not push too much for an immediate consideration of the issue in the UNDC, nevertheless the cases of individual states could not be ignored. During the consideration of establishing new NWFZs, the representatives of some developing countries, including Nepal and Afghanistan, displayed great interested in the issue. However, in the final text of the UNDC's guidelines, agreed upon in 1999, Mongolia was unable to have any reference to the concept of a single-state NWFZs reflected, due to the reluctance of the P5 and the application of the rule of consensus when adopting the text of these guidelines. At that time Mongolia did not want to be seen as abusing the consensus rule for its own benefit. However, on its insistence a footnote to the guidelines made reference to the initiative and stated that the status had been welcomed by the General Assembly in $1998 .{ }^{17}$

15 See document A/CN/10/195 of 22 April 1997

16 See UNGA document A/C.1/51/L.29 of 29 October 1996

17 See Report of the Disarmament Commission. General Assembly Official Records. Fifty-fourth session. Supplement No. 42 (A/54/42). Foot note "g" of the guidelines read as follows: Owing to its unique geographical circumstances, Mongolia has declared its nuclear-weapon-free status in order to promote its security. This status was welcomed by the General Assembly in its consensus resolution 53/77 D of 4 December 1998. 
The promotion of a novel concept of single-state NWFZs was not an easy task and needed proper conditions for in-depth discussion. However, the practical establishment of one such zone would be useful in demonstrating its utility, feasibility and importance. But Mongolia's purpose in the General Assembly was not to promote the concept as an abstract possibility, but to raise this issue first and foremost in the practical context of gaining the General Assembly's recognition of Mongolia's declared single-state NWFZ.

The 1975 United Nations comprehensive study of NWFZs had envisaged the possibility of the establishment of NWFZs in 'individual countries', while international practice has de facto seen the establishment of single-state nuclear-weaponfree zones in Latin America until the Tlatelolco treaty entered into force in October 2002. ${ }^{18}$ Long before the entry into force of the Tlatelolco treaty the P5 had ratified its Protocol II, thus de facto and de jure providing security assurances to individual States until the entry into force of the Treaty. ${ }^{19}$ Also in the Treaty on the Final Settlement with Respect to Germany ${ }^{20}$ the two German states and the four nuclear-weapon states agreed that no foreign armed forces and no nuclear weapons or their carriers would be stationed in the German Democratic Republic or deployed there, thus de facto and de jure making it a single-state NWFZ.

\section{b) working for a separate UNGA resolution on Mongolia's status}

$(1997-98)$

In parallel to working through the UNDC to promote the concept of a singlestate NWFZ and without waiting for its outcome, Mongolia thought it important to have the issue considered by the General Assembly itself, preferably in the First Committee that dealt with disarmament and security issues. Before proceeding to work with the P5 representatives in the General Assembly on a resolution that would recognize Mongolia as a NWFZ, Mongolia needed to study the position of each nuclear-weapon State regarding NWFZs and, bearing that in mind, draft a paper that would contain the ideas that it would want to see in the future - either in a traditional UNGA disarmament resolution or in a separate resolution. Although it would have been easier to add a paragraph in a generally accepted UNGA resolution on NWFZs or on regional security, it was thought that the purpose would be better served if Mongolia would go for a separate resolution, since that would allow the international community to focus specifically on the issue without mixing it with other related issues.

With that in mind, in the summer of 1997, Mongolia prepared a draft resolu-

18 The treaty specified that the full zone would not enter into force until it was ratified by all States within the zone. That did not occur until Cuba ratified the treaty in 2002. However, the treaty permitted individual States to waive that provision and declare themselves bound by the treaty, which many did beginning with Mexico in 1968.

19 Thus the United Kingdom deposited its instrument of ratification of Protocol II in 1969, followed by the United States in 1971, China and France in 1974 and the Soviet Union in 1979.

20 Better known as the Two Plus Four Treaty. 
tion as a trial balloon, seeking the reactions of the P5. The draft in its preambular part made reference to the 1975 comprehensive UN study of the question of NWFZs in all its aspects, which had, inter alia, recognized the right of individual countries to establish NWFZs. In its operative part, the draft recognized and provided support for Mongolia's nuclear-weapon-free-status and invited its neighbors and other nuclear weapons states to cooperate with Mongolia in institutionalizing this status. It called upon states to respect and support Mongolia's independence, sovereignty, territorial integrity, and nuclear-weapon-free status and requested the Secretary-General and the relevant UN bodies to extend assistance to Mongolia in institutionalizing the status. The draft also requested the Secretary General to report on the implementation of the resolution at the subsequent session of the UN General Assembly and include in the agenda of the subsequent (fifty-third) session an item entitled "Mongolia's nuclear-weapon-free status".

The draft, as it turned out, presented many difficulties for the P3 (i.e. US, UK and France). Thus, US Ambassador J. King, speaking also on behalf of UK and France, cautioned against using the term "zone". He indicated that although such language had been used in some past statements, the terminology had acquired more sensitive legal connotations in light of the US signing of the protocols to the Rarotonga and Pelindaba treaties, as well as of the ongoing discussions on how to approach the Bangkok Treaty. That was why, he argued, more time was needed for P3 government legal experts to carefully study the issue. The P3 inquired about Mongolia's real objectives: did it want a full status as a NWFZ with all the legal assurances and requirements that go with it; or guarantees for its territorial integrity and freedom from aggression; or simply some sort of special recognition of its unique geographical status, since it bordered only with two nuclear-weapon states. The P3 also expressed concern regarding the notion of "institutionalizing the status" and therefore needed further clarification from the Mongolian side. Turning to the operative part of the draft, the US wondered about the role of the UN Secretary General and relevant United Nations bodies, which could have, in their view, important operational and financial implications. Bearing in mind all of the above questions and queries, and that there was little time to work on the necessary drafting changes which surely required consultations with Washington and the other P2 capitals, the US representative thought that it was impossible to do the necessary legal and political analysis in time to decide on instructions for the work of the First Committee in October-November 1997. Ambassador J. King expressed the hope that Mongolia would not table the resolution during that session and cautioned that lack of support for the resolution by the P5 would undermine the fundamental political objective that Mongolia was trying to achieve.

The Mongolian delegation tried to respond to some of the issues raised. It pointed out that its objective and goal had been clearly reflected in the draft reso- 
lution itself, that it wanted an international recognition of its unique status as a state sandwiched between two nuclear-weapon states and wanted legally binding assurances from the P5 that they would not only respect the status of total absence of nuclear weapons on its territory, but would not do anything that would contribute to the violation of that status. Being a land-locked country with limited access to the outside world, and limited economic leverage and political influence, Mongolia had usually found itself easily "influenced" by its giant neighbours in its dealings with the outside world. Mongolia's independent foreign policy needed overall security assurances not only from Russia and China, but also from the other P3 since they were all permanent members of the Security Council and each one had a veto power on issues of international security. Since Mongolia had border treaties with its immediate neighbors and was enjoying good-neighborly relations with both of them, there was no need to have a guarantee for its territorial integrity. Mongolia then expressed its willingness to work on the actual drafting of the resolution since, in its view, there was still ample time for such drafting work. Ambassador J. King pointed out that although the draft resolution did not make any reference to Mongolia in principle, in fact it was promoting the concept of a single-state NWFZ and that was not acceptable.

Mongolia's response was communicated by the United States to the other P4. The P5, having consulted among each other on Mongolia's draft resolution and its response to the US suggestions, decided to signal their displeasure with Mongolia's plans. Thus, on 9 October 1997 the P3, i.e. US, UK and France made joint demarches in Ulaanbaatar, Geneva and Moscow whereby they warned Mongolia that any attempt to go beyond its political declaration of 1992 (i.e. President P. Ochirbat's declaration of Mongolia as a NWFZ) towards a legally-binding format would be seen as a departure from the recognized concept of NWFZs, and would raise difficult issues of principle which the P5 would need to consider very carefully. The P3 noted that Mongolia already benefited from the general security assurances of the P5 reflected in Security Council resolution 964 of 11 April 1995 and that the P5 took those assurances very seriously. The gist of the demarche was to warn that tabling a resolution of the type that was being presented unofficially would be "premature, unhelpful and possibly counterproductive" and to urge Mongolia not to table it in the First Committee. When asked whether reference to P5 meant that Russia and China also were part of the demarche, the answer was that they were aware of the joint demarche but were not directly involved with the demarche itself.

At that time both sides were determined to pursue their objectives. Mongolia thought that the chances of the adoption of the resolution by overwhelming majority in the First Committee were high and that is why it worked with the NAM countries to garner the widest possible support for the draft resolution. It thought 
its cause was just and understandable for all, and that not only the P5 themselves supported in principle Mongolia's initiative but also the NAM as a group was supportive of Mongolia's policy which was in line with the spirit of the earlier NAM pronouncements on the issue as well as the successfully negotiated Pelindaba and Bangkok treaties that established NWFZs in Africa and South-East Asia respectively.

Sensing possible complications regarding the draft resolution, the European Union took the initiative to try to help both sides to come to some agreement. Thus, Belgian delegate on behalf of the EU the Mongolian delegation and suggested that the best way out might be not to press for a resolution at that session of the General Assembly with an understanding that in the subsequent year the P5, the EU and others could agree to a separate resolution on Mongolia's initiative. It was also suggested that perhaps Mongolia could think of promoting the initiative not as a "zone", which the P5 were not prepared to accept, but rather in the vague form of a "status".

After having consulted with Ulaanbaatar, the Mongolian delegation agreed not to have a separate resolution at that session. It was agreed later with the US delegation, which was now acting on behalf of all P5, that informal consultations would be needed before the next session of the Assembly and that one of the possible ways would be to have such consultations during the forthcoming session of the UNDC in the spring of 1998. The United States indicated that it was ready to meet with Mongolia separately to understand better the latter's policy objectives behind the initiative.

\section{c) defining the scope and content of the first resolution (1998)}

After having agreed in 1997, in principle, to have the General Assembly adopt in 1998 a separate resolution on Mongolia's nuclear-weapon-free status, Mongolia and the US (as agreed among the P5) held a number of informal meetings to better understand the position of each side and on that basis to try to come to an agreement on a possible UNGA resolution in the fall of 1998.

Thus, in December 1997, representatives of Mongolia and the US met on the margins of the signing Conference for the Landmines Convention held in Ottawa on 2-4 December and exchanged information on the positions of Mongolia and the P5 on the issue and how to proceed further. Although no concrete decision was taken during that meeting, both sides agreed that they should be creative and bear in mind the wider legitimate security interests of each side.

In January 1998, the two sides met again in New York where they continued the work to better understand the interests of each other. The Mongolian side explained the main aims of its post-Cold War foreign policy and how it saw the challenges and opportunities of the emerging security environment. Thus, it was 
underlined that its interest lay largely with ensuring the country's external national security primarily by political and legal means, and that it did not foresee any nuclear or military threat from its neighbors. However, after the collapse of the Soviet Union and the withdrawal of Russian troops from Mongolia, a virtual security vacuum had emerged that could easily be filled by either of the two neighbors or by another great power if they thought this was warranted by their security 'imperatives' or 'needs'.

The dual goal of Mongolia was, it was pointed out, (1). to ensure that no great power would be allowed to use Mongolian territory inter alia for stationing nuclear weapons or parts of systems thereof to the detriment of the interests of other powers or of regional stability in general and (2) not being part of any political or military alliances, Mongolia was interested in having a well-defined and internationally agreed status that would include security assurances of the P5 tailored to Mongolia's geopolitical location.

The US side was interested in understanding further the political rationale behind Mongolia's initiative and the proposed resolution, in case there would be one. Doubt was raised as to whether a single State could be considered as a credible zone. The Mongolian side quoted the 1975 comprehensive study on NWFZs as the basis of its policy and of tacit international support. The US was also interested in the positions of Russia and China on the issue and, if a General Assembly resolution were to be adopted, what would Mongolia do after its adoption. The Mongolian side said that its neighbours were well aware of Mongolia's policy and in principle supported it, and that when the General Assembly adopts a separate resolution on the issue, that would allow Mongolia to work further to actually institutionalize the zone by concluding an international treaty to that effect. The US side left the meeting with the understanding that Mongolia's preoccupation with its security was more of a political nature than military. It was also understood that Mongolia was looking beyond a resolution and nuclear security assurances to a wider political and legal assurances of the great powers. Both sides agreed to meet again before the UNDC session in 1998.

On the margins of 1998 UNDC, as agreed, the Mongolian and US representatives met to discuss the possible steps that could lead to the adoption of a General Assembly resolution on the issue. The Mongolian delegation came to the meeting with a non-paper in the form of a draft resolution regarding Mongolia's nuclearweapon-free status to sound out the position of the P5 (see Annex-3). It was quite an ambitious draft (there was an understanding in the Mongolian delegation that an ambitious draft would cover most of the areas of Mongolia's interest, enable it to sound out individual and collective reactions of the P5 to the issues raised and provide some room for diplomatic bargaining and agreement). In return, as an inducement, the draft referred to the issues as a nuclear-weapon-free status, and 
not as a single-State zone. The author is reproducing in extenso the main provisions of the draft resolution so as to show the areas of special interest of Mongolia.

\section{Mongolia's ambitious draft resolution}

The draft had 12 preambular and 8 operative paras. The preambular part for example, welcomed the decision of Mongolia, located between two nuclearweapon states, to declare its territory a NWFZ, noted with satisfaction the earlier separate Statements made by the P5 regarding Mongolia's declaration, expressed the belief that the nuclear-weapon-free status of Mongolia would contribute to enhancing stability and confidence-building in the region and promote Mongolia's security by strengthening its independence, sovereignty, territorial integrity, inviolability of its borders and preservation of its ecological balance. It would have expressed the conviction that for the nuclear-weapon-free status to be credible, the status needed to have a sound international legal basis and be verifiable.

The operative part of the draft recognized and supported Mongolia's nuclear-weapon-free status, welcomed its good-neighborly and balanced relationship with its two neighbors, invited them and other nuclear-weapon states to cooperate with Mongolia in institutionalizing the status and called upon Member States to respect and support its independence, sovereignty, territorial integrity, inviolability of its frontiers, preservation of its ecological balance and its non-aligned foreign policy. To make the resolution more effective, as in a draft presented in 1997, it requested the Secretary General to assist Mongolia in institutionalizing the status, to report on the implementation of the resolution the subsequent year, and include in the provisional agenda of that subsequent session a separate item entitled "Mongolias nuclear-weapon-free status".

Many provisions of this draft formed the basis of the first General Assembly resolution on the item. Since the UNODC session and bilateral meetings had shown that the P5 had difficulties in accepting a single-state NWFZ as a concept, the Mongolian side decided not to raise unnecessary difficulties from the beginning of the process. Thus, it was decided not to use the word "zone" in the title of the draft but rather to use the ambiguous notion of "status". The US representative took the draft and promised to share it with other $\mathrm{P} 4$ and get back with some feedback.

At the bilateral meeting both sides agreed that Mongolia's security needed to be looked at from a broad angle, in line with Mongolia's national security concept, and not only from a narrow strategic and military perspective. The US representative hinted that the P3 (US, UK and France) were working on a joint proposal to be made to Mongolia sometime in June, and that Russia and China were aware of that proposal and could, at some stage, even co-sponsor it.

When the Mongolian delegate asked for some specifics of the planned P3 
proposal, the US delegate said that it would amount to adopting a number of documents, including perhaps two General Assembly resolutions: one welcoming Mongolia as a permanent neutral country and the second promoting greater cooperation and good-neighborliness in the region of Mongolia. Moreover, Mongolia might think of concluding a border security treaty with its neighbors like the one that Russia had concluded with China and its Central Asian neighbors. He also mentioned that the $\mathrm{P} 3$ were also thinking of proposing to Mongolia and China that they conclude a treaty whereby the latter would commit to respect Mongolia's policy of prohibiting the stationing of nuclear and other weapons of mass destruction in Mongolia (as Russia had committed to in 1993 in its treaty with Mongolia).

The Mongolian delegate promised that its side would carefully consider the proposals upon their formal presentation, but as of that moment he did not see valid reasons for Mongolia to abandon the policy of institutionalizing its nuclear-weapon-free zone status and acquiring security assurances from the P5. The Mongolian representative said that the best and shortest way to address the issue of institutionalizing Mongolia's status would be to adopt a substantive resolution in 1998 followed by conclusion of a trilateral treaty between Mongolia and its neighbors that would define Mongolia's status and provide it with the assurances to which the other P3 could accede at some stage, as well as the adoption of a more or less procedural resolution by the General Assembly in 2000 that would seal and close the entire deal. The US representative cautioned not to force the single-state NWFZ issue ${ }^{21}$ and promised to consider carefully the proposals to be made in June 1998 in Geneva. Referring to its non-paper, the Mongolian representative said that it could be revised bearing in mind the outcome of the Geneva meeting and the meeting of Mongolian Foreign Minister's council ${ }^{22}$ scheduled in August 1998.

\section{d) P3 four-point proposal}

At the June 1998 Geneva meeting of representatives of the US, UK, France and Mongolia, the P3 formally introduced their proposals which they believed could better achieve Mongolia's fundamental objectives of international support for its independence, sovereignty and territorial integrity than a formal recognition of Mongolia's NWFZ through a UNGA resolution. They were of the view that a single-state NWFZ concept could raise difficulties for them and other states if applied under other circumstances. With this in mind the $\mathrm{P} 3$ proposed four ideas

21 UNDC in its report on the work for 1997 pointed out that the issue of single-state NWFZ attracted the attention of the Commission, while its work for 1998 underlined the need to actively consider all aspects of the issue of establishing single-state NWFZ.

22 The Minister's council consists of the Minister and some other senior officials of the Ministry of Foreign Affairs of Mongolia and takes decisions on issues of within the Ministry's competence or makes proposals to the Government of Mongolia or the National Security Council. 
of a more political nature that, in their view, could help Mongolia achieve its foreign policy objectives. The proposals were as follows:

First, Mongolia could table a resolution at the 1998 UN First Committee and General Assembly that would recognize the "permanent neutrality of Mongolia", similar to the one that Turkmenistan had tabled in 1995 and which was adopted by consensus.

Second, an additional UNGA resolution could be tabled in 1999 that would urge greater cooperation and comity among the States of the region, a concept similar to that which had inspired a series of resolutions regarding the development of good-neighborly relations among the Balkan States. Third, Mongolia could conclude a border security treaty with its neigh bors similar to the 1996 treaty concluded among Russia, China, Tajikistan, Kazakhstan, and Kyrgyzstan. The agreement could focus on transparency measures for conventional forces, including advance notification of maneuvers, restrictions on the scale, geographical limits and the number of troop exercises, and an agreement that a party's military forces would not be used to attack another party or conduct any military activity threatening the other party and thus upsetting calm and stability in the border area.

Fourth. In the 1993 Mongolian-Russian treaty on friendly relations and cooperation, Russia officially committed itself to respect Mongolia's policy prohibiting the stationing of nuclear and other weapons of mass destruction on its territory. Perhaps, Mongolia could also seek similar treaty-based recognition of its non-nuclear status from China. The P3 expressed the hope that the Mongolian side would consider these ideas and would respond soon.

The Mongolian side thanked the P3 for the proposals which were indeed novel and interesting and enquired whether the Russians and Chinese were aware of these proposals. He was told that both Russia and China were aware of them. Thus, when the Chinese representative was told about the possible border treaty, the response was that China and Mongolia already had border and border regime treaties and that is why they did not have any border problems. When the P3 inquired if that would indicate that conclusion of such a treaty was even more possible, the Chinese representative in principle agreed and promised to convey the $\mathrm{P} 3$ proposal to Beijing. As for the Russian side, Mongolia was told that it was supportive and had even expressed its readiness to co-sponsor these proposals. However, since China was not co-sponsoring it, it was thought not proper for Russia to co-sponsor without China, the $\mathrm{P} 3$ was told by Russia.

The Mongolian representative thanked the $\mathrm{P} 3$ for their interesting proposals and promised to take them up at the forthcoming internal consultations in Ulaanbaatar and to respond after the consultations. At the same time he made some brief preliminary comments regarding some of the points reflected in the propos- 
als. Thus, he asked what was meant by "permanent neutrality", since Mongolia was pursuing in practice a policy of neutrality with respect to possible disputes among its two neighbors only. He said that in cases of imbalances in power and geographical handicaps, such as lack of independent access to the sea and markets, it was difficult to maintain a credible permanent neutral policy. Moreover, neutrality could be more credible if it were based not on a political declaration but on an international agreement or treaty. As for Turkmenistan's neutrality, he agreed that in 1995 the General Assembly had indeed approved a resolution that expressed support for that country's declared permanent neutrality. However, General Assembly resolutions in themselves were not guarantees. Moreover, Turkmenistan's neutrality resolution did not envisage any implementation nor verification mechanism. It would be another issue if neutrality would have an international legal basis, in which case he stated that Mongolia might be willing to seriously consider it The P3 responded that neutrality could start with the General Assembly resolution.

As for a border security treaty, the Mongolian representative said that his country had no territorial or border problems with its two neighbors; in fact it had border demarcation and border regime treaties with both of them, and therefore he saw no urgent need to conclude a border security treaty. He reiterated that Mongolia's nuclear-weapon-free status could be strengthened by first adopting in 1998 a substantial General Assembly resolution that could in 1999 be followed-up by the conclusion of a trilateral treaty between China, Russia and Mongolia that would define the latter's nuclear-weapon-free status, and in 2000 by the adoption of a second resolution in support of the trilateral treaty.

The P3 indicated that they were aware of Mongolia's policy, however they were still reluctant to support such action since that might set a precedent that might affect Japan and its policy, for example. That was precisely why the P3 was making the afore-mentioned four proposals.

The representative of Mongolia underlined the importance of institutionalizing the status through concluding an international treaty. The P3 responded that they would be prepared to support a General Assembly resolution that they would be proposing and that in itself would amount to guaranteeing its implementation. In the end it was agreed that the Mongolian side would get back with an official reaction to the P-3 proposals sometime in August.

\section{d) decision of the Minister's council}

The Minister's council met on 3 July 1998 and, having heard the report of Mongolia's Permanent Representative to the UN on the issue, agreed to promote Mongolia's nuclear-weapon-free status in three stages: 1) to have the General Assembly adopt in 1998 a resolution regarding Mongolia's status that would wel- 
come its good-neighborly relations with Russia and China, call upon these three countries to conclude a treaty regarding Mongolia's independence, sovereignty, territorial integrity and its nuclear-weapon free status and have the General Assembly welcome and support the status: 2) to work for a trilateral treaty in 1999 and 2000 whereby Russia and China would commit to respect Mongolia's independence, sovereignty, territorial integrity, nuclear-weapon-free status, inviolability of its frontiers, economic security and ecological balance; and 3) to work for the adoption by the General Assembly in 2000 of a resolution that would welcome the trilateral treaty between Mongolia, Russia and China and ask the General Assembly, the Security Council, and the Secretary General to assist in an appropriate manner in implementing the treaty. With this mandate, the Mongolian delegation went to the General Assembly to start working for its implementation.

\section{e) Response to the P3 four-point proposal}

Based on the decision of the Minister's council meeting, the Mongolian side, as a first step, sent the following response to the P3 regarding their four-point proposal in a form of a memorandum:

"The Mongolian side has carefully studied the ideas presented by the P3 Ambassadors, in close consultation with the representatives of Russia and China, on 12 June 1998 in Geneva in connection with Mongolia's single-State NWFZ concept. Mongolia believes that the $\mathrm{P} 3$ proposals are a positive indication that the US, UK and France, like Russia and China, fully understand and support its desire to seek international recognition of its unique political and security situation and institutionalize it as such. The ideas put forward by the P3 (permanent neutrality of Mongolia, good-neighborly relations with Russia and China and conclusion of a border security treaty with them) are a vivid manifestation thereof.

Being a small State sandwiched by two nuclear neighbors, Mongolia is genuinely interested in safeguarding its non-nuclear status which would be in the interests of Mongolia as well as its neighbors, especially in their strategic calculations and hence for the predictability and stability of the region.

Mongolia has declared its territory a NWFZ, which enjoys the broadest support of the international community, including of the P5. The next logical step for Mongolia is to have the General Assembly recognize and support the status, as it has done with respect to other zones, since the Assembly itself has declared as far back as in 1975 that the nuclear-weapon-free zones ..."shall, as a rule, be recognized as such by the General Assembly of the United Nations. "However, we are aware that though the P5 understand and support Mongolia's nuclear-weaponfree status, the single-State NWFZ concept at present causes difficulties for the P5 if applied in other circumstances. Therefore they are prepared to deal with Mongolia's case as an exception. 
Bearing in mind Mongolia's foreign policy orientation, its good-neighborly relations with the two neighbors and the position of the P5 with respect to Mongolia's case as well as the single-State NWFZ concept, the Mongolian side is proposing the following:

First, Mongolia agrees with the three step approach to addressing this question, namely the adoption by the 53rd General Assembly of a resolution on Mongolia's international security status (in order not to emphasize solely the NWFZ status), conclusion with its neighbors of a trilateral treaty that would address the external security related issues of Mongolia and a second resolution after the trilateral treaty has been concluded.

Second, this year Mongolia could table, as agreed in principle, a resolution in the First Committee that would welcome and recognize Mongolia's nuclear-weapon-free status; take note of the importance of this status for enhancing stability in the region as well as for strengthening Mongolia's independence, sovereignty and territorial integrity; welcome Mongolia's good-neighborly and balanced relationship with its neighbors; invite Mongolia's neighbors as well as other nuclear-weapon States to cooperate with it in institutionalizing its nuclear-weapon-free status as an important basis of its national security and call upon all States to respect Mongolia's status. A draft resolution to this effect is annexed to this memorandum.

Third, Mongolia could conclude a treaty of a general political nature with its neighbors on its security and nuclear-weapon-free status. Many of the provisions of the treaty could be drawn from the treaties of friendly relations and cooperation that Mongolia has concluded with its neighbors separately in 1993 and 1994 respectively. Since the treaty would deal to some extent with Mongolia's nuclear-weapon-free status, perhaps the P3 could express their support for the treaty in one form or another (protocol, joint declaration).

Fourth, the General Assembly, perhaps at its 55th session, could welcome the conclusion of the treaty and its support by the P3 mentioned above and call upon all States to respect and support Mongolia's status."

The draft resolution that was annexed to the Mongolian response differed very little from the non-paper presented to P5 Ambassadors in April (as reproduced as Annex 3). The only major difference was that the title of the resolution would have read "Mongolia's security and nuclear-weapon-free status".

\section{Negotiating the text of the first resolution}

\section{a) Response to Mongolia's draft resolution}

The written response of the United States to Mongolia's ambitious draft resolution mentioned above, which had been annexed to the Mongolia's memorandum 
regarding the $\mathrm{P} 3$ proposals, came on 23 September. It was an extensive response, harsh and critical. It said that the preambular paragraph, including references to NWFZ, needed to be reduced and quotation marks be added to "nuclear-weaponfree zones" so as to make it clear that that was Mongolia's characterization of itself, and not a recognized NWFZ. Reference to "sound international legal basis" needed to be deleted since it was not clear what was meant by it. Likewise, reference to verifiability of the status needed to be deleted since, as it stood, it could have implied a more extensive system of verification other than that already conducted by the IAEA.

With regard to the operative part, the US response suggested that reference to "institutionalization" needed to be defined as institutionalizing its nuclearweapon-free status through appropriate declarations of support and to refrain from taking actions inconsistent with Mongolia's nuclear-weapon-free status. It was emphasized that the US did not support creating new international "institutions" (i.e. agencies, organizations, implementing bodies or procedures requiring international actions) that would expressly support Mongolia's self-declared nuclear-weapon-free status. It was also unclear, the US said, from the grammatical construction whether "other nuclear-weapon States" was synonymous with "Mongolia's neighbors" or meant the P3 as well. The US thought that operative paragraph 6, which would have requested the Secretary General and relevant UN bodies to extend the necessary assistance to Mongolia in institutionalizing and sustaining its status, needed to be either deleted entirely or, alternatively, the phrase "within existing resources and without prejudice to existing UN commitments, obligations and priorities" needed to be added after "necessary assistance". Even in that case US would still be concerned over the meaning of the terms "institutionalization" and "sustaining". What did Mongolia mean by "institutionalization", US asked. In general, this would imply creating some institution for implementation, oversight etc.

A few days later, on 29 September, without waiting for Mongolia's response to the written comments presented above regarding the latter's draft resolution, the United States conveyed its own preliminary ideas in the form of a draft resolution based, it said,, on the Mongolian draft. The main difference was that in the operative part of the US draft, the General Assembly, instead of 'recognizing and supporting' Mongolia's status, would only 'take note' of the declaration by Mongolia of its nuclear-weapon-free status, and instead of 'inviting' Mongolia's neighbors and other nuclear-weapon States to cooperate with it in institutionalizing the status', it would merely 'ask member States to emphasize their respect for Mongolia's status.' There were other drafting changes as well.

Before Mongolia had the chance to formally react to the US proposal, the P3 met separately and decided to produce their joint draft resolution (the United 
States and France were to tasked to draft it). The new P3 draft was soon communicated to the Mongolian side.

On 2 October, the US and Mongolian representatives met to update each other on the latest developments and exchange views of the possible common draft resolution. The United States once again expressed its opposition to the idea and the use of the term "institutionalization". Mongolia explained that institutionalization did not necessarily mean establishing new institutions but rather meant laying the legal basis for Mongolia's nuclear-weapon-free status. The two sides agreed to disagree on this issue. They agreed also to speed-up the drafting of the resolution and, if possible, to finalize it before the Mongolian representative would make his statement in the First Committee on 14 October 1998 and indicate his government's position on the issue. The United States informed that though both Russia and China were aware of the drafting work underway, neither would participate in the actual drafting, since they believed that they had already expressed their views on Mongolia's status and that if they would participate in the negotiations together with the P3 their policy might look inconsistent.

The Mongolian side learned on 13 October that the P5 Ambassadors had met and decided to present their joint (not P3 but P5) draft in the next days. As to the actual drafting, Russia said that it needed instructions from Moscow, while China declared that it would support but not participate in the drafting itself.

\section{b) P5 joint draft resolution}

On 16 October 1998, the United States presented to Mongolia two draft resolutions: version A co-sponsored by United States, United Kingdom, Russia and France; and version B, a possible counterproposal by Mongolia. The A version was almost a reproduction of the earlier US version of the draft resolution except that Russia was co-sponsoring it as well, while reference to inviting member States to emphasize their respect for Mongolia's status had been deleted. It meant that the gist of the resolution would be to 'take note' of Mongolia's declaration instead of 'recognizing' and 'supporting' the NWFZ status. Any reference to institutionalization was also absent. Therefore, version A was a priori unacceptable for Mongolia. The P4 anticipated Mongolia's negative reaction to version A and therefore they had prepared a "more acceptable" one for Mongolia - a version B.

Version B was also more or less a reproduction of version A, but contained three main differences. One was that the operative part, instead of 'taking note' of Mongolia's declaration, would 'welcome' it. Two other novelties were additional operative paragraphs that would invite Russia and China "to cooperate with Mongolia in taking the necessary measures trilaterally to consolidate and strengthen Mongolia's independence, sovereignty, territorial integrity, inviolability of its 
frontiers, nuclear-weapon-free status, ecological balance and non-aligned foreign policy" and requested the Secretary General and relevant UN bodies to provide the necessary assistance to Mongolia, within existing resources, to take the necessary measures enumerated above.

Version B of the draft resolution was a step in the direction of officially acknowledging Mongolia's initiative and placing emphasis on trilateral measures to promote it (in line with Mongolia's goal of concluding a trilateral treaty with its neighbors on defining its nuclear-weapon-free status). However, since the resolution would be the first that would pave the way for other subsequent resolutions (in case such resolutions would be needed) Mongolia believed that its major interests were not adequately reflected in version $\mathrm{B}$. That is why Mongolia took the initiative of producing a version $\mathrm{C}$ based on its own original draft and some provisions of version $\mathrm{B}$.

\section{c) Negotiating version $\mathrm{C}$}

The main gist of the new Mongolian draft (version C) was to have General Assembly welcome the declaration by Mongolia of its nuclear-weapon-free status and invite its two neighbors to cooperate with it in consolidating and strengthening the status (as indirectly implied by in operative paragraph 3 of version B). Mongolia also used the draft to revive some of its previous proposals, such as recalling the separate Statements of support for Mongolia's initiative made by the P5, underlining that nuclear-weapon-free status was one of the means of ensuring national security of states and expressing the conviction that Mongolia's internationally recognized status would contribute to enhancing stability and confidence-building in the region. Although version B placed emphasis on trilateral cooperation, it did not envisage any role for the P3. That is why the Mongolian draft called upon other nuclear-weapon states (meaning the P3) and the entire UN membership to respect and support the status.

Version C was presented to the P5 on 19 October for their consideration. Russia asked for some time (2-3 days) to carefully study the draft and consult with Moscow. Though China was supportive of the draft, it wondered why the draft laid so much emphasis on Mongolia's two neighbors, and proposed to invite not only Russia and China but all P5 to cooperate with Mongolia. In that spirit it suggested deleting the request to the Secretary General to assist in the trilateral cooperation. China also saw no need to call upon Member States to respect Mongolia's status since it was obvious from the spirit of the draft in the first place. Mongolia agreed in principle with the comments and promised to bear them in mind when working further on the draft.

With most of the provisions of the draft resolution agreed with the P5 in principle, the operative paragraph 3 which dealt with the trilateral cooperation be- 
came the focus of real negotiation. Thus, the United States proposed deleting any mention of the P5 and instead suggested to call upon all members of the UN to cooperate with Mongolia. In response, Mongolia underlined that in a larger context the issue was related to nuclear weapons and thus to the P5 as permanent members of the Security Council. Therefore, it argued, the P5 should be mentioned, if not in operative paragraph 3, and suggested to call upon the "interested States". During subsequent drafting, Mongolia deleted references to trilateral cooperation both in operative paragraph 3 and in the paragraph that would have requested the Secretary General to provide assistance, so as to reduce the difficulties that these paragraphs could cause Russia and China at that stage. With these changes the draft was finally submitted to UN Secretariat for circulation as a working document of the First Committee (the draft appeared on 23 October 1998 as document A/C.1/53/L.10).

After circulation of the draft resolution L.10, the United States suggested that in operative paragraph 3 the term "interested States" needed to be changed to "States concerned" since, depending on their geographical location, nuclearweapon states played different roles. Since there was no other major problem with the rest of the draft resolution, the Mongolian side agreed to the suggestion. With this change the draft resolution was re-issued as document L.10/Rev.1.

The draft resolution L.10/Rev.1 was introduced by Mongolia in the First Committee on 29 October 1998. The Mongolian representative underlined that this was a product of long serious consultations and delicate negotiations. It was pointed out that for a small state with Mongolia's geopolitical location, its status would be stronger and more durable if its overall security were to be internationally recognized and guaranteed. That understanding formed the basis of the very concept of the draft resolution and of the approach to the question in general. Looking to the future, he said that with such understanding and the necessary political will it would be possible to arrive soon at a concrete, special arrangement that could accommodate both the particular needs and interests of Mongolia and the legitimate interests of its neighbors and of stability in the region in general. He pointed out that the soul of the resolution was its operative paragraph 3 which proceeded from the notion that its nuclear-weapon-free status was part of Mongolia's overall security and that therefore consolidation and strengthening of its international security was a sine qua non for ensuring its nuclear-weapon-free status. Therefore that operative paragraph would invite all "States concerned" to cooperate with Mongolia in that regard.

After the draft had been introduced, the Chinese delegate approached the Mongolian delegation with a list of proposed last minute changes to the draft, which he read out. When asked whether these proposals could be made formally in a written form since the draft resolution had already been circulated and 
introduced in the First Committee, he said that these were only oral proposals for Mongolia to think about. Thus, he suggested to change operative paragraph 3 that referred to "States concerned" to "Member States, including the five nuclearweapon states" so as to make sure that all of the P5 would be asked to cooperate with Mongolia. He also proposed to reflect in the preambular part a reference to the five principles of peaceful coexistence, delete the preambular paragraph that underlined the importance of an internationally recognized status of Mongolia, and in the operative part to delete all the paragraphs except for the ones that would welcome Mongolia's declaration of its nuclear-weapon-free status, ask the Secretary General to report on the implementation of the resolution and inclusion of the item in the provisional agenda of one future General Assembly session. Sensing that China was not insisting on its proposals, Mongolia agreed only to the change to be made in operative paragraph 3, and later that day asked the Secretariat to make that change and issue the document as L.10/Rev.2.

\section{d) A flurry of proposed amendments to the revised draft}

With document L.10/Rev.2 circulated among delegates and just a few days before its official re-introduction in the First Committee, China and France became unusually active in proposing changes to the draft. Thus, France proposed in the preambular part to delete the gist of NAM's support for Mongolia's initiative (which referred to institutionalization of the single-State nuclear-weaponfree status). It also proposed to delete in the operative part of the draft a reference to the P5 as well as any reference to a follow-up report by the Secretary General and to the inclusion of the item in any future provisional agenda of the General Assembly.

China proposed five changes in the draft: in the preambular part to add one paragraph that would note with appreciation Mongolia's reaffirmation of its determination to honor the obligations that it had undertaken under the NPT and delete in the preambular part the provisions that would underline the importance of Mongolias internationally recognized nuclear-weapon-free status and made reference to Mongolia's security interests. In the operative part it proposed that some minor drafting changes be made concerning Mongolia's relations with its neighbors. It also proposed to add a new paragraph that would read as follows: "Welcomes the undertaking by Mongolia as a member of the NPT not to receive the transfer of nuclear weapons or other nuclear explosive devices or of control over such weapons or acquire nuclear weapons or other nuclear explosive devices, and not to seek or receive any assistance in the manufacture of nuclear weapons or other nuclear explosive devices" (a quote from Article II of the NPT).

Faced with a barrage of last-minute proposals that needed some form of reaction or response, the Mongolian delegation drew up its own counterproposal 
which inter alia, underlined that establishment of NWFZs could contribute to the achievement of general and complete disarmament, emphasized the importance of internationally recognized agreements on the establishment of NWFZs and in an operative part urged the states concerned, especially the nuclear-weapon states, pending the establishment of the zone, to take appropriate measures to strengthen Mongolia's status. These written counterproposals of Mongolia were communicated to France and China, which played their role in "restraining" the other two "last minute enthusiasts" to press their proposed amendments. These last-minute changes, if debated, could have delayed the consideration of the draft resolution and action on it in the First Committee, since the deadline for submitting draft resolutions and taking action on them was quickly approaching.

When the date of the introduction of L.10/Rev.2 and taking action on the draft had been set, first Japan, then China and India asked for time-out to consult with their capitals. On 10 November the Mongolian representative introduced L.10/ Rev.2 in the Committee. He said that Mongolia and its negotiating partners had approached the issue creatively and mindful of the prevailing political realities. As a result of the consultations held since October 1997, it had been agreed that Mongolia's nuclear-weapon-free status would be credible and durable only if its over-all security were ensured and internationally recognized. He pointed out that this understanding had formed the basis of the very concept and the spirit of the approach of the states concerned to it, and had been reflected in the draft resolution.

Explaining the need for the second revision, the Mongolian delegate pointed out that it was connected with a request by one of the "States concerned" to make it absolutely clear that all five nuclear-weapon states would be equally involved, and that this emphasis had found reflection in the sole change that had been made in operative para 3 , where the words "States concerned" had been replaced by the words "Member States, including the five nuclear-weapon states".

\section{e) Adoption of the resolution}

During the consideration of the draft resolution in the First Committee, Pakistan's Ambassador (who thought that the Committee was in the process of adopting another draft resolution dealing with nuclear testing in which Pakistan and India were being blamed) has asked for a 10-minute delay in the adoption of the decision. The Mongolian delegation was taken by surprise and wondered whether one of the P5 was behind the move. However, having been told that the resolution dealt with Mongolia's draft, Pakistan withdrew its request for the delay.

The draft resolution was adopted on 10 November 1998 without a vote (see Annex-4). Explanations of vote (EOV) were made by Australia, Canada, Chili, China, Egypt Jamaica, Macedonia, Malaysia, Republic of Korea, San Marino, and 
the United States.

Of the delegates that made EOVs, of particular interest were the EOVs of China and of the United States.

The Chinese delegate pointed out that he understood and supported the desire and efforts of Mongolia to establish a single nuclear-weapon-free state status and that China would respect and support such a status. He underlined that as a neighbor of Mongolia, China fully respected the sovereignty, independence and territorial integrity of Mongolia and supported its independent foreign policy.

Ambassador Grey of the United States pointed out that the political cooperation which the resolution called for was expected to lead to significant international security benefits for Mongolia as well as for the states that participated in the process. He underlined that the United States had supported the resolution because Mongolia's unique geographic and security situation merited unique consideration. He said that he wanted to correct a misperception that the resolution called for the establishment of a single-state NWFZ. He said that a close examination of the text would reveal that Mongolia had moved beyond such a concept and was looking to a broader range of measures to increase its international security, and that this broader approach would yield important security benefits for Mongolia and for the international community.

On 4 December 1998 the plenary of the General Assembly considered the report of the First Committee and took action on the proposed resolutions and a decision. The draft resolution regarding Mongolia's status was adopted without a vote. In taking the floor to explain its vote and the importance of the resolution, the Mongolian delegate expressed optimism regarding future practical steps, explaining that this optimistic view was based on the good-neighborly relations and cooperation that Mongolia enjoyed with all states, and especially with its two neighbors, both of which had concluded treaties on friendly relations and cooperation with Mongolia. In a broader context, he underlined, bearing in mind the weight that these two neighbors and other nuclear-weapon states had in international relations, a well-balanced set of arrangements could play an important role in enhancing further stability in that strategic region.

\section{Conclusion}

The aim of this article was to shed some light on the amount of work that was needed to promote Mongolia's initiative and have the General Assembly of the United Nations adopt its first resolution regarding Mongolia's nuclear-weaponfree status. The author tried to show that good will, cooperation and a joint search for acceptable compromise can yield positive outcomes. Multilateral diplomacy is a tool that can bring large and small states together to address common issues and challenges. Competition and cooperation are two sides of multilateral diplomacy. However, on the other hand, the negotiations also showed that when it comes to 
nuclear issues, even if they did not deal with any nuclear threat but were intended to contribute to mutual trust, the P5 are still often hesitant to move beyond Cold War mindsets and are usually hesitant to entertain or accept fresh ideas and initiatives.

The first General Assembly resolution on Mongolia's nuclear-weapon-free status was a landmark in Mongolia's quest for credible security assurances. It paved the way for pursuing the issue within a multilateral framework. The resolution invited Member States, including the P5, to work with Mongolia "to ... consolidate ... its nuclear-weapon-free status". In response to that 'invitation', in 2000 the P5 made a Joint Statement on providing security assurances to Mongolia in connection with its nuclear-weapon-free status. Although it might sound impressive, what the P5 did was merely to announce that their non-binding, highly caveated declarations on security assurances to NPT non-nuclear weapon states ... applied to Mongolia. For Mongolia, which was successfully developing good-neighborly relations with Russia and China, it was "surprising" to be given P4 assurances which announced the ... conditions under which nuclear weapons would not be used or threatened to be used against it. This Joint Statement clearly demonstrated that still much more needed to be done to acquire the security assurances tailored to Mongolia's specific geopolitical conditions. On the other hand, China confirmed its well-know general strategic position that it would not use or threaten to use nuclear weapons against non-nuclear-weapon States or NWFZs at any time or under any circumstances.

The reader might be tempted to ask what Mongolia really wanted to gain from its initiative. The Cold War years had vividly demonstrated to Mongolia that, just like other small states with a nuclear-weapon-state neighbor it could be drawn into a possible nuclear stand-off between nuclear-weapon states and thus "be targeted" by various pressures to accept elements of nuclear-weapon systems or serve as a potential accomplice "in association or alliance" with a nuclear-weapon state.

In reality, Mongolia is not a party to any political-military alliance or grouping, nor does it want to be. The best way for Mongolia to ensure its security, and thus contribute to regional peace and understanding, is by promoting further goodneighborly relations with Russia and China and, bearing in mind its geopolitical circumstances, by developing a special regime that would recognize Mongolia's neutrality in great power rivalries or disputes. Such a regime, which could be based on Mongolia's internationally defined and recognized nuclear-weapon-free status, could, as Mongolia had suggested, consist of a trilateral treaty with its immediate neighbors as mentioned in this article, a P3 protocol to that treaty in its support, and an overwhelming international support in the form of a General Assembly resolution.

The twelve years since the adoption of the first General Assembly resolution, especially the results of the NPT Review conferences amply demonstrate that the 
cold war mindset is still prevalent and, therefore, it would take enormous efforts, persistence and, what is more important, courage and political will to move towards a safer world. Thus it took enormous efforts on the part of Mongolia and twelve more years for the P5 to finally recognize Mongolia's status and provide assurances to respect that status and not to contribute to any act that would violate it. It will still take more efforts to duly institutionalize the status and make an important part of the emerging XXI nuclear security architecture.

Vienna, December 2012 


\section{Annex-1}

\section{U.S. statement of 6 October 1993}

The Government of the United States commends the Government of Mongolia on its demonstrated adherence to the principles of the 1968 Treaty on the Non-Proliferation (NPT) of Nuclear Weapons, to which Mongolia and the United States are parties, and on its decision in this spirit to declare Mongolia a nuclearweapon-free zone. In this connection, we also welcome Mongolia's decision to support the indefinite extension of the NPT in 1995.

In adhering closely to the letter and spirit of the NPT, Mongolia, as a non-nuclear sovereign State friendly to the United States, benefits from the United States' commitment to seek Security Council assistance for non-nuclear-weapon States who are members of the NPT in the event of a nuclear attack on them, and from U.S. assurances that it would not use nuclear weapons against a non-nuclear State not allied with a nuclear-weapon State. We note that other nuclear-weapon States have provided similar assurances.

If Mongolia ever faces a threat and decides to refer the matter to the United Nations Security Council, the United States, along with other members of the Council, would consider appropriate steps to be taken.

\section{Annex-2}

$\underline{\text { Draft }}$

\section{JOINT STATEMENT OF NUCLEAR-WEAPON STATES CONCERNING MONGOLIA'S DECLARATION OF A NUCLEAR-WEAPON-FREE ZONE}

We, the undersigned nuclear-weapon States,

Recognizing that the creation of nuclear-weapon-free zones could contribute to the strengthening of the regime of non-proliferation of nuclear weapons and to security of States,

Recognizing the importance of Mongolia's declaration of her territory as a nuclear-weapon-free zone for strengthening confidence and predictability in Central Asia, and in the Asia-Pacific region in general,

Recalling the United Nations Security Council resolution of 19 June 1968 concerning security guarantees for non-nuclear-weapon States as well as the unilateral declaration by nuclear-weapon States concerning Mongolia's declaration of her territory as a nuclear-weapon-free zone, aking into consideration Mongo- 
lia's commitment not to produce, place or allow the stationing on her territory of nuclear weapons or their component parts, as well as her commitment to allow international inspections,

Declare that we shall respect the nuclear-weapon-free status of Mongolia. If Mongolia ever faces a threat and decides to refer the matter to the United Nations Security Council, we, along with other members of the Council, would consider appropriate steps to be taken, as provided in the UN Charter.

New York, “ “ August 1994

Annex-3

Mongolia's nuclear-weapon-free status

(non paper by Mongolia, April 1998)

The General Assembly,

Recalling the purposes and principles of the Charter of the United Nations;

Recalling further the Declaration of Principles of International Law concerning Friendly Relations and Cooperation among States in accordance with the Charter of the United Nations;

Recalling its relevant resolutions concerning the establishment of nuclearweapon-free zones, including paragraphs 60-62 of the Final Document of the Tenth Special Session of the General Assembly, the first special session devoted to disarmament;

Recalling further its resolution 3472 B (XXX) of 11 December 1975 whereby it underlined that a nuclear-weapon-free zone shall, as a rule, be recognized as such by the General Assembly of the United Nations;

Welcoming the decision of Mongolia, located between two nuclear-weapon States, to declare its territory a nuclear-weapon-free zone;

Taking note with satisfaction of the separate statements made by the nuclearweapon States in connection with Mongolia's declaration of its territory a nuclearweapon-free zone; 
Bearing in mind the Final Document of the XII Ministerial Conference of the Movement of the Non-Aligned Countries held in New Delhi n April of 1997, whereby it welcomed the efforts of Mongolia to institutionalize its nuclear-weapon-free status;

Reiterating its conviction that the establishment of nuclear-weapon-free zones and areas in various parts of the world are important means of contributing effectively to the objectives of non-proliferation of nuclear weapons, and general and complete disarmament, as well as to ensuring the security of the concerned states;

Proceeding from the fact that nuclear-weapon-free status is one of the means of ensuring the national security of States;

Bearing in mind its resolution 49/31 of 9 December 1994 on the protection and security of small States;

Believing that the nuclear-weapon-free status of Mongolia will contribute to enhancing stability and confidence-building in the region as well as promote Mongolia's security by strengthening its independence, sovereignty, territorial integrity, inviolability of its borders and preservation of its ecological balance;

Convinced that for the nuclear-weapon-free status to be credible it should have a sound international legal basis and be verifiable;

1. Recognizes and supports Mongolia's nuclear-weapon-free status;

2. Welcomes Mongolia's good-neighborly and balanced relationship with its neighbors as an important element of strengthening regional peace, security and stability;

3. Invites Mongolia's neighbors, other nuclear-weapon States to cooperate with Mongolia in institutionalizing its nuclear-weapon-free status as an important basis of its national security;

4. Calls upon States members of the United Nations to respect and sup port Mongolia's independence, sovereignty, territorial integrity, inviola bility of its frontiers and preservation of its ecological balance as well as its non-aligned foreign policy;

5. Appeals to the member States of the Asia-Pacific region to support Mongolia's efforts to join the relevant regional security and economic arrangements;

6. Requests the Secretary-General and relevant United Nations bodies to extend the necessary assistance to Mongolia in institutionalizing and sustaining its nuclear-weapon-free status;

7. Requests further the Secretary-General to report on the implementation of this resolution at its fifty-fourth session;

8. Decides to include in the provisional agenda of its fifty-fourth session an item entitled "Mongolia's nuclear-weapon-free status". 


\section{Annex-4}

\section{MONGOLIA'S INTERNATIONAL SECURITY AND NUCLEAR-WEAPON-FREE STATUS}

(General Assembly resolution 53/77 D)

\section{The General Assembly,}

Recalling the purposes and principles of the Charter of the United Nations,

Recalling also the Declaration of Principles of International Law concerning Friendly Relations and Cooperation among States in accordance with the Charter of the United Nations, ${ }^{23}$

Welcoming the decision of Mongolia to declare its territory a nuclear-weaponfree zone,

Taking note with satisfaction of the separate statements made by the nuclearweapon States in connection with Mongolia's declaration of its territory a nuclearweapon-free zone,

Bearing in mind the Final Document of the Twelfth Conference of Heads of State or Government of Non-Aligned Counties, held at Durban, South Africa, from 29 August to 3 September $1998^{24}$, in which the Conference welcomed and supported Mongolia's policy to institutionalize its single State nuclear-weaponfree status,

Proceeding from the fact that nuclear-weapon-free status is one of the means of ensuring the national security of States,

Bearing in mind its resolution 49/31 of 9 December 1994 on the protection and security of small States, Welcoming Mongolia's active and positive role in developing peaceful, friendly and mutually beneficial relations with the States of the region and other States,

Convinced that the internationally recognized status of Mongolia will contribute to enhancing stability and confidence-building in the region as well as promote Mongolia's security by strengthening its independence, sovereignty and territorial integrity, the inviolability of its borders and the preservation of its ecological balance,

1. Welcomes the declaration by Mongolia of its nuclear-weapon-free status;

2. Endorses and supports Mongolia's good-neighborly and balanced rela tionship with its neighbors as an important element of strengthening 
regional peace, security and stability;

3. Invites Member States, including the five nuclear-weapon States, to cooperate with Mongolia in taking the necessary measures to consolidate and strengthen Mongolia's independence, sovereignty and territorial integrity, the inviolability of its borders, its economic security, its ecological balance and its nuclear-weapon-free status, as well as its independent foreign policy;

4. Appeals to the member States of the Asia and Pacific region to support Mongolia's efforts to join the relevant regional security and economic arrangements;

5. Requests the Secretary-General and relevant United Nations bodies to provide the necessary assistance to Mongolia, within existing resources, to take the necessary measures mentioned in paragraph 3 above;

6. Requests the Secretary-General to report to the General Assembly at its fifty-fifth session on the implementation of the present resolution;

7. Decides to include in the provisional agenda of its fifty-fifth session an item entitled "Mongolia's international security and nuclear-weapon-free status".

$79^{\text {th }}$ plenary meeting

4 December 1998 